\title{
Available Techniques of Wastewater Management Practices in Indian Tanneries: A Literature Review
}

\author{
Manali Bhaduri \\ Department of Energy and Environment, Symbiosis Institute of International Business, Pune, India \\ Received: 03/09/2020 \\ Accepted: 04/01/2021 \\ Published: 20/06/2021
}

\begin{abstract}
Tanning is the process of turning animal hide into leather. The manufacturing process leads to the generation of wastewater, which must be treated before discharge. The treatment processes of this wastewater in India was examined. A systematic review based on Preferred Reporting Items for Systematic Reviews and Meta-analysis (PRISMA) guidelines was carried out on the electronic database Google Scholar from 2010 to 2020. Wastewater treatment practices in Indian tanneries were looked for and 64 relevant reports and articles were shortlisted and studied. The results showed that coagulation with alum and ferric chloride gave the best results in primary treatment, aerobic and anaerobic processes gave the best results when combined, and tertiary treated water could be reused.
\end{abstract}

Keywords: Wastewater treatment, Indian tanneries, Primary treatment, Biological treatment, Tertiary treatment, Biosorption, Membrane processes, Activated sludge process

\section{Introduction}

A tannery is a place where animal hides are processed or tanned with the use of various, usually harmful, chemicals to make leather (1). They are one of the most water and labour intensive and highly polluting industries today (2). Tanning involves three broad processes- pre-tanning in which hides or skins are cleaned; tanning process, which permanently stabilizes the hides and post-tanning or finishing operations, where final shape value is added for manufacturing of leather (3). The wastewater generated from these processes must be treated before discharge. The treatment of tannery wastewater leads to the generation of sludge laden with chromium that makes it hazardous (4). This sludge can lead to soil pollution if it is not disposed of properly (5).

Tannery wastewater is dark brown and it is foul-smelling, probably due to the presence of large amounts of organic and inorganic substances (6). The presence of organic compounds is characterized by high biological oxygen demand (BOD) and chemical oxygen demand (COD) which deplete dissolved oxygen in the water bodies that they are discharged into (7). Besides these, high salinity, nitrogen, suspended solids, sulphate, sulphide and suspended solids make it difficult for aquatic life to survive $(8,9)$. These chemicals make the wastewater highly acidic and are further accompanied by phosphates, calcium and magnesium (10). Chromium is one of the biggest threats to living beings especially when it is in the form of hexavalent chromium $(11,12)$. It gets absorbed into cells faster and could accumulate in lungs kidney, red blood cell etc. and change their functionality (12).
Studies have shown that chromium and its compounds, beyond a certain level, can damage DNA by breaking its single and doublestrands (13). It can also cause skin allergies, dizziness, reproductive problems among other issues as well (14). Among fishes, structural alteration could occur due to chromium (15). Not only do all of these pollutants affect aquatic life, but also the humans or animals which are dependent upon these water bodies. Groundwater pollution and soil pollution is a problem many residents living close to tanneries have to deal with (16). This makes groundwater unsuitable for irrigation and soil unsuitable for crop growth (17). Different techniques have been employed in India to treat tannery wastewater before its discharge like physical, physico-chemical, electrochemical and biological treatments. These are practised in India besides more advanced techniques like reverse osmosis (RO), ozonation and membrane processes (18).

The objective of this paper is to review the wastewater treatment techniques used in the tannery industry. The pieces of literature have been studied in details and improvement to an existing process has been suggested. A recommendation has also been provided based on the most economic option for reuse of treated water from a tertiary treatment process.

\section{Background}

Tanning has been carried out since time immemorial. Before the discovery of chrome tanning method, different tanning processes like aluminium tawing, smoke tanning and oil tanning were employed globally. 3000-year-old leather manufactured by

Corresponding author: Manali Bhaduri, Department of Energy and Environment, Symbiosis Institute of International Business, Pune, India. E-mail: manali.bhaduri2019@siib.ac.in 
Egyptians gave evidence for oil tanning (14). However, the most popularly used method to tan hides in tanneries worldwide today is chrome tanning (2). Chrome tanning is faster and cheaper, but as a big portion of it ends up in the effluent as sludge, its disposal becomes a problem. The use of nanoparticles in tanning is slowly making its way into tanneries and silver nanoparticles have been found to render anti-microbial, UV-resistant and anti-fungal properties to leather (14).

Pollution control related measures have been adopted by Indian tanneries since the latter half of the 1980s after international bans and domestic regulations forced Indian tanneries to embrace more environmentally friendly methods of manufacturing leather. In 1996, the Supreme Court made it mandatory for tanneries to attach themselves to a Common Effluent Treatment Plant (CETP) or an Individual Effluent Treatment Plant (IETP). Most Indian tanneries now have pollution control devices (19). ETPs fall under two categoriesregistered and unregistered. Registered firms are required to have an on-site Primary Effluent Treat Plant (PETP) and connected to a CETP if an IETP is absent, while no such mandate has been declared for unregistered firms (1). There are close to 200 IETPs in India (20). The number of CETPs in India in 2018 was 19 with 17 of them operating in the States of Uttar Pradesh, Tamil Nadu and West Bengal. 13 of them are in Tamil Nadu, 3 in Uttar Pradesh and 1 in West Bengal (1).

To review the treatment processes, the different processes involved in tanning have to be understood first. Pre-tanning, as mentioned earlier, refers to the cleaning of hides. First, the skins are salted for prevention from rotting and this is called curing. After this, soaking is done to wash away the salt and impurities and to increase moisture. Liming and unhairing for the removal of skin proteins are done to ready it for tanning. After this, fleshing is done. This is followed by deliming and bating to remove lime and increase $\mathrm{pH}$ in a drum. For bating, the proteolytic enzyme is used in the same drum operation. This drum also houses the next processes of pickling and chrome tanning. Basic chromium sulphate is used for chrome tanning and this makes it one of the most polluting processes in tanning (21). If vegetable tanning is used, it occurs in two steps, penetration and fixing. The former process diffuses tannins, which comprise a complex mix of phenols, into the skin while latter binds collagen with the penetrated tannins (14). Vegetable tanning is a slower and more costly process (22). After this, in post tanning operations, neutralization and bleaching are done, followed by retanning, dyeing, and fatliquoring in a single vessel. Other properties to enhance leather properties like water repellence and abrasion proofing may be added. At last, finishing operations take place to make the hide softer and to cover natural scars or marks by treating it with an organic solvent or water-based dye and varnish (23). For every ton of hide processed, about $300 \mathrm{~kg}$ chemicals are used (24). The wastewater released annually amounts up to 9420 kilolitres (25).

The methods to treat the wastewater generated from these processes will be covered in the results section.

\section{Methodology}

\subsection{Search strategy}

Keywords like "wastewater treatment in Indian tanneries", "activated sludge process" and "biosorption" were used to search the Google Scholar database. A time period of 10 years from 2010 to 2020 was allotted and citations and patents were included. The search strings provided about 13,900 results, out of which 63 finally were selected and analysed. All 63 items were of an openaccess type and include journal articles, book sections, conference proceedings and thesis documents. The report by CPCB on global best practices was retrieved from the India Environment Portal website.

\subsection{Study selection}

For screening purposes on Google scholar, the titles and abstracts were analysed and 78 articles were shortlisted. After this initial screening, the 78 shortlisted documents were screened further by checking for the location of tanneries, tannery processes, the impact of tannery effluents and methods of wastewater treatment solely in India by reading the introductions and conclusions. This resulted in the elimination of 15 papers that did not match the secondary screening parameters mentioned above. The search strings were not modified to find specific articles on tannery processes or their impacts. Thus 63 documents, comprising journal articles, book sections, conference proceedings and thesis documents, have been analysed to understand the wastewater treatment effectiveness of different processes typically used in India.

The detailed methodology with the use of PRISMA guidelines is given below:

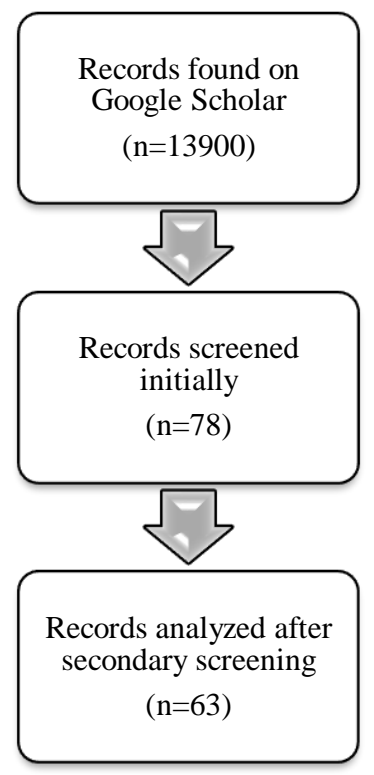

\subsection{Data collection}

Data for the systematic review of wastewater treatment in Indian tanneries were collected through the 63 relevant literature articles which were examined. For a better understanding of wastewater treatment of tannery effluent, articles which were chosen covered tanning process in use today and its evolution, the impact of tannery effluent on the environment and living beings and last but not the least, wastewater treatments in use in India for the last decade. CPCB's report was used to understand the best available techniques in tannery effluent treatment at a CETP in Tamil Nadur, India. The pros and cons of the processes from retrieved literature have been assessed to provide recommendations. Risk of bias in individual studies involves not 
taking exact costs of implementation or operation of various techniques into consideration, the review of open-access documents alone and the assumption that the research techniques of multiple methods are accurate and consistent.

\section{Results}

\subsection{Primary Treatment}

Coagulation and flocculation as mentioned above, are primary treatment methods. Chemical coagulation requires the addition of coagulants which help colloidal particles to aggregate into largersized particles, which may then be sedimented or flocculated (26). Flocculants enable the agglomeration. This may be carried out by the use of alum or ferric chloride or the combination of both (27). Best results are achieved by the combination of both (26). For vegetable tanneries, use of poly aluminium chloride with flocculants gives good results for the removal of TSS, COD and colour (27). The use of these chemicals to treat tannery wastewater leads to the generation of toxic sludge (4). The process of precipitating contaminants by the use of the direct current in an electrolytic environment followed by flocculation with or without the addition of coagulant is called electrocoagulation (Ahmed Samir Naje, 2013).

Table 1: Primary Treatments

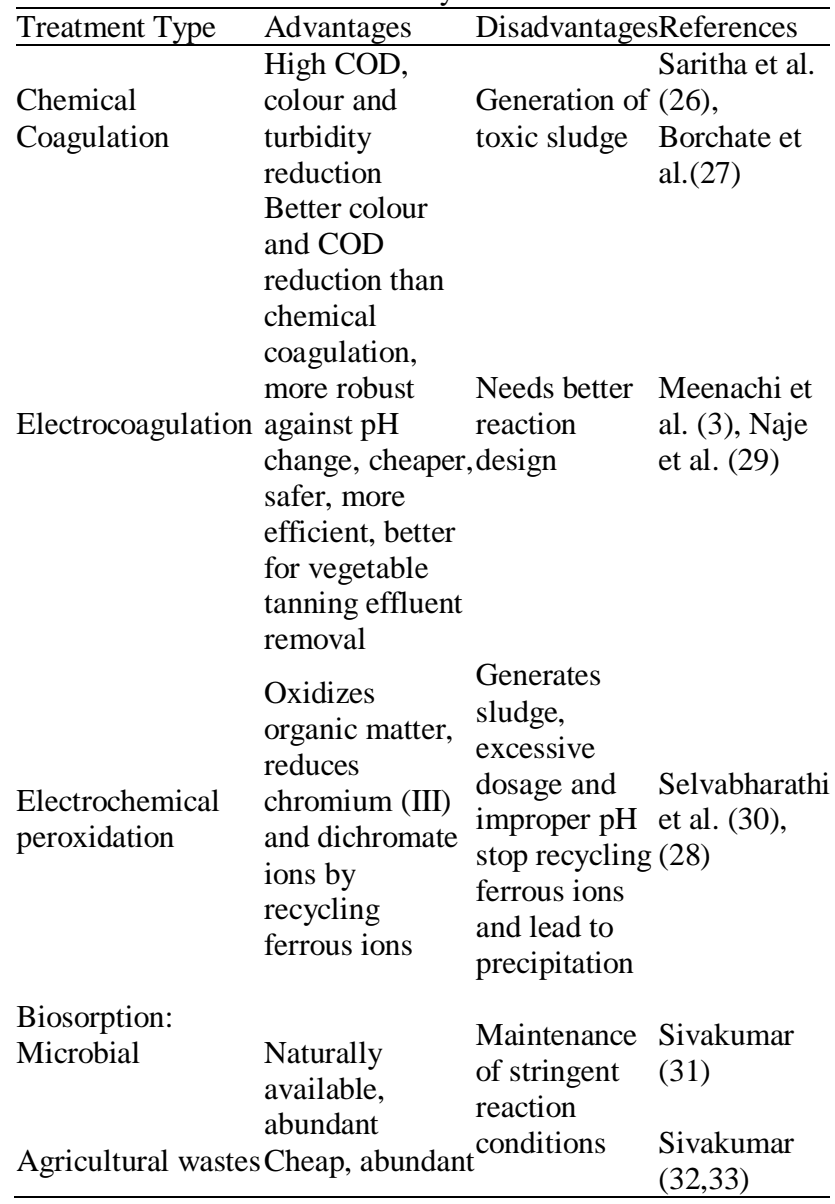

It is also beneficial in terms of cost and safety while having high efficiency, but it needs better reactor design and there is scope for a better understanding of the process and its control (3). The use of hydroxyl ions from Fenton's Reagent $\left(\mathrm{Fe}^{2+}+\mathrm{H}_{2} \mathrm{O}_{2}\right.$, comes under advanced oxidation processes (AOPs) and this can be carried out as a primary or tertiary treatment (28). It is prudent to remove as much chromium from the wastewater as possible because it is inhibitory to the growth of the microbes used in biological treatment (21). The removal of chromium by metabolic or physico-chemical uptake by biological materials is called biosorption $(34,35)$. When technologies with living organisms are used to reduce the toxicity of contaminants, it is called bioremediation (7).

Table 2: Bio sorbents

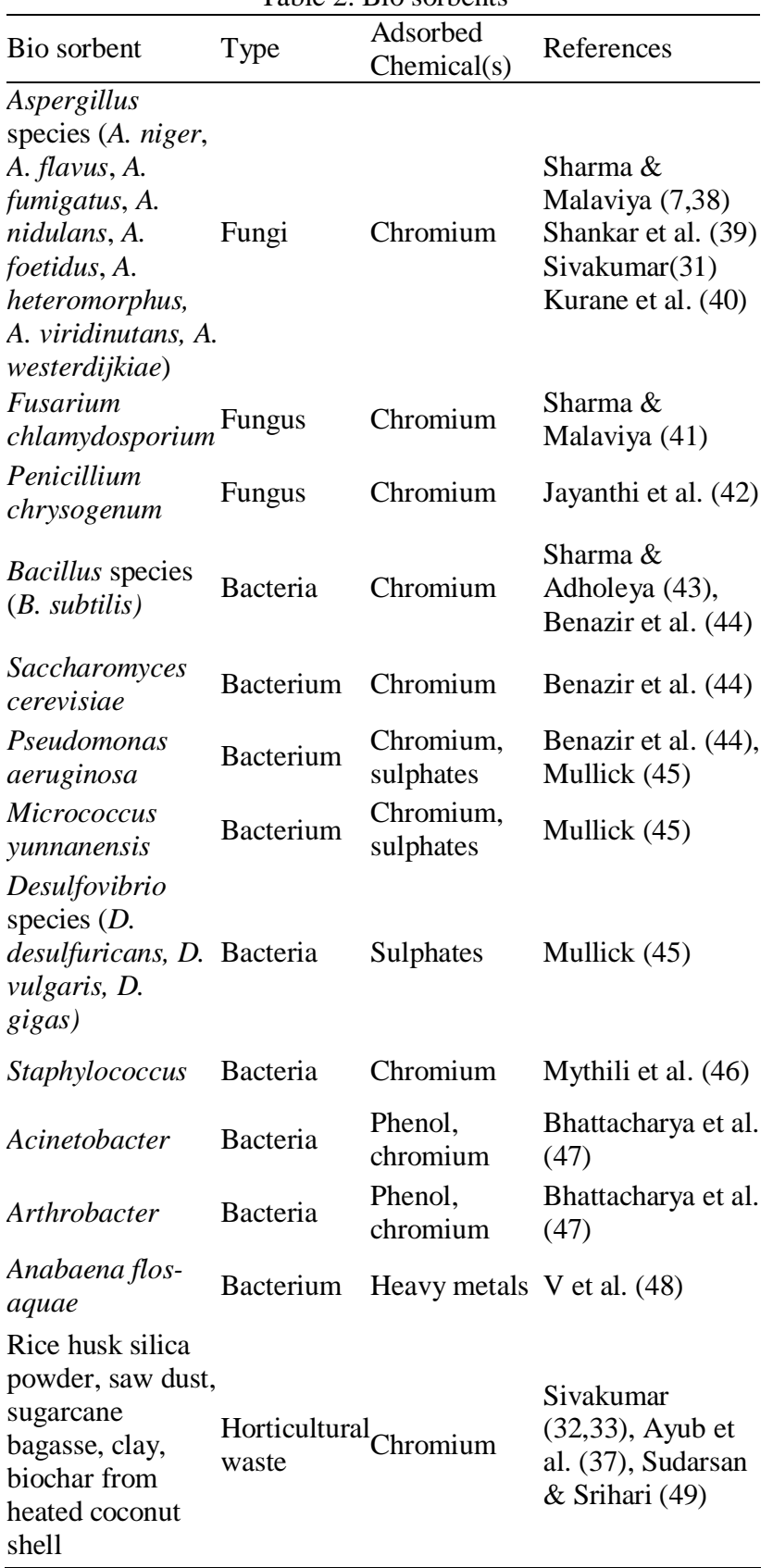


Many different microbes like different species of bacteria and fungi can be used bio sorbents and have been highlighted as such in many literary documents (36). Activated carbon was used earlier but it is expensive and other alternatives have been explored (37). Constructed wetlands are wetlands with controlled environments used for filtering, volatilizing, microbial-mediated processing (MMP), sedimentation, sorption, and many more. Biochar from heated coconut shell can be used as an adsorbent in constructed wetlands (49). Though constructed wetlands are low cost, they are discouraged in India due to odour issues (20).

\subsection{Secondary Treatment}

Secondary treatment involves activated sludge-based treatment, forced aeration by surface aerators and recycling of activated sludge (Manikant Tripathi S. K., 2019). It is carried out via biological means to treat organic effluents in the wastewater and can be done by aerobic, anaerobic or anoxic processes (18). Aerobic processes do not release odour but they release a huge amount of sludge. The salinity of tannery wastewater can also hamper the treatment process. Anaerobic treatments are more favourable in tropical environments and they generate less sludge and consume less energy (22). Their efficiency can be monitored by their ability to generate biogas (50). Activated sludge processes (ASPs), Sequential batch reactor (SBR), Up flow anaerobic sludge blanket (UASB), Membrane Sequential Batch Reactor (MSBR), Up flow Anaerobic Fixed Biofilm Reactor (UAFBR) and Sequential Batch Biofilm Reactor (SBBR) are used in biological treatment (20).

Activated sludge comprises microorganisms in an aerated environment and for designing an ASP reactor, factors like influent flow rate, surface area, length and scour velocity are taken into consideration (25,51). At Unnao, in Uttar Pradesh, India, a CETP is present that employs ASPs. In it, large particles are first screened and then mixed completely by air diffusers at the bottom of an equalization tank. The effluent is then pumped into the flash tank for $\mathrm{pH}$ adjustment through chemical dosing. After this, suspended solids settle by flock formation and it is removed. Effluent is then treated aerobically in aeration tanks and colloidal particles, that settle down in clarifiers is drained through terminal main hole (52). The use of pure oxygen with a catalyst (manganese sulphate) aids sulphide reduction and it has been proven to be twice as effective as aeration while lowering energy costs incurred due to running aerators and keeping them in good condition (53).

SBRs work in five processes- fill, react, settle, draw and idlein aerated conditions. First, the reactor is filled with wastewater, then it is aerated and allowed to react by continuous stirring. After this, separated solids are allowed to settle while remaining unaffected by effluent currents. In the next step, the clarified supernatant water is removed using decanters and finally, equalization, which is the removal of solids from sludge or sludge wasting and biomass mixing, can be done (54). SBRs are popular because they are cheap and can combine aerobic and anaerobic processes in one reactor (55). They perform better than ASPs in terms of nitrification and denitrification.

UASBs are better for energy recovery, they produce lesser sludge, lower odour and lower emission of methane and carbon dioxide but sulphur compounds and varying organic loading rate and hydraulic retention time can affect its efficiency $(20,56)$. A CETP at Jajmau in Uttar Pradesh, India uses UASB for tannery wastewater treatment. Compared to the CETP in Unnao that employs ASP, the Unnao plant has performed better in the removal of BOD, COD and chromium probably because ASP involved prior removal of chromium. Sulphide inhibition was blamed for the poorer performance of UASB (20). Sulphur and chromium removal by electrooxidation or catalytic oxidation with magnesium sulphate or nickel sulphate to reduce sulphides concentration may be carried out prior to biological treatment to prevent sulphur-compounds' ability to affect UASB efficiency. $82.68 \%$ and $76.83 \%$ removal of COD and sulphide have been observed with oxygen injection with manganese sulphate as a catalyst in aerated conditions, not in a UASB reactor (53). The same could be combined to increase the UASB's efficiency.

UAFBR can also be used as an alternative to other anaerobic technologies although sulphur toxicity needs to be taken into account before its administration (20).

Biofilm reactors have good specific removal rates due to the higher concentration of biomass. An SBBR combined with ozonation can remove COD, $\mathrm{NH}_{4}-\mathrm{N}$ and TSS up to $97 \%, 98 \%$ and $99.9 \%$, respectively $(20,53)$. Sulphate reduction can be achieved through sulphate-reducing bacteria. MSBR has proven to reduce ammonium and COD after sulphur from the tannery wastewater has been removed by oxidation. The cost of this technology may, however, make it difficult to implement (20).

Table 3: Comparison of biological treatment performances

\begin{tabular}{|c|c|c|c|c|c|}
\hline Metho & $\begin{array}{l}\text { Untreated } \\
\text { Effluent }\end{array}$ & Unit & $\begin{array}{l}\text { Treated } \\
\text { Effluent }\end{array}$ & $\begin{array}{l}\text { Reduction } \\
\%\end{array}$ & Reference \\
\hline ASP & $\begin{array}{l}\text { pH: } 8.1 \pm 0.1 \\
\text { COD: } \\
2016 \pm 2.0 \\
\text { BOD: } \\
1520 \pm 10.0 \\
\text { Cr: } 62.38 \pm \\
88.21\end{array}$ & $\begin{array}{l}\mathrm{Mg} / \mathrm{L} \\
\mathrm{Mg} / \mathrm{L} \\
\mathrm{Mg} / \mathrm{L}\end{array}$ & $\begin{array}{l}\text { pH: } 6.8 \pm 0.1 \\
\text { COD: } \\
224 \pm 1.0 \\
\text { BOD: } 40 \pm 5.0 \\
\text { Cr:5.48 } \pm \\
2.42\end{array}$ & $\begin{array}{l}88.9 \\
97.4 \\
86.98- \\
95.32\end{array}$ & $\begin{array}{l}\text { Ramteke } \\
\text { et al. (52) }\end{array}$ \\
\hline SBR & COD: 1908 & \multicolumn{3}{|c|}{$\mathrm{Mg} / \mathrm{L} \mathrm{343.44-381.680-82 \%}$} & $\begin{array}{l}\text { Suresh et } \\
\text { al. (55) }\end{array}$ \\
\hline $\begin{array}{l}\text { SBBR- } \\
\text { Ozonat } \\
\text { on }\end{array}$ & $\begin{array}{l}-\mathrm{COD} \\
\mathrm{iNH}_{4} \mathrm{~N} \\
\mathrm{TSS}\end{array}$ & NK & NK & $\begin{array}{l}97 \\
98 \\
99.9\end{array}$ & PC (20) \\
\hline MSBR & $\begin{array}{l}\text { COD } \\
\text { Ammonium } \\
\text { Nitrogen }\end{array}$ & \multicolumn{2}{|c|}{$\mathrm{Mg} / \mathrm{L}_{90}^{550}$} & $\begin{array}{l}90 \\
\sim 100 \\
60-90\end{array}$ & $\mathrm{PC}(20)$ \\
\hline
\end{tabular}

\subsection{Tertiary Treatment}

For tertiary treatment, RO, ultrafiltration (UF), ozonation and phytoremediation may be carried out. Membrane processes include microfiltration (MF), nano-filtration (NF), UF and RO (22). Chemicals may also be used to get rid of COD (57). They can help in the recovery of chromium which can be used again for tanning (22).

One of the first polymeric membranes to be used for UF or RO was cellulose acetate, along with a pore-forming agent, synthetic polyether polyethylene glycol (PEG). Clogging of the pores due to the effluents being subjected to the membrane for an extended period can reduce its efficiency to remove chromium. At an appropriate $\mathrm{pH}$, chromium reduction with a novel UF membrane made from cellulose acetate, polyethylene glycol and nanochitosan can vary from $90 \%$ to $39 \%$ depending on the contact 
time and subsequently varying porosity of the membrane. Similarly, BOD and COD reduction of $56 \%$ and $51 \%$ respectively have been observed after an extended contact time. The maximum removal of chromium was noted at neutral $\mathrm{pH}$ with a membrane thickness of $0.2 \mathrm{~mm}$ and $100 \mathrm{kPa}$ pressure and industrial application of this has been suggested (58).

Low pressure, polymeric membranes may be used for MF or UF for providing RO feed water but tannery wastewater contains fine suspended solids which can block pores of these membranes and lead to permanent fouling because it is difficult to clean. Turbidity should be maintained below 1 nephelometric turbidity units (NTU) to prevent the permanent fouling of these membranes. Ceramic MF membranes are more advantageous than polymeric membranes as their high porosity supports the separation of higher turbidity and colloidal impurities to produce good feed for the RO process. Ceramic membranes can even be used for pre-treatment of raw tannery wastewater as this will reduce the steps involved in conventional treatment. Following this with RO through the polymeric membrane can produce permeate suitable for reuse in the tanning process. Leather produced with the aid of treated water has been reported to have better physical properties in terms of dye acceptance and tensile strength as compared to leather manufactured by freshwater. A reduction of $91 \%$ in COD and $\mathrm{BOD}_{5}, 62 \%$ in total organic carbon (TOC) and turbidity reduction below 1 NTU was observed after MF. After RO, 99\% of TOC, $82 \%$ of sodium and turbidity reduction to 0.025 NTU was achieved (59). Phytoremediation uses plants in constructed wetlands to convert toxic compounds into non-toxic compounds. It has aesthetic advantages and it is sustainable but it can only be used for water with low contamination (22). RO treatment is expensive but it can give fantastic results for the removal of TDS and chlorides (60). One of the main disadvantages of membrane processes includes the biofouling of the membrane.

Ozonation and the use of ultraviolet (UV) radiation fall under advanced oxidation processes. Hydrogen peroxide can also be used for this, along with catalysts like iron, manganese and titanium dioxide $\left(\mathrm{TiO}_{2}\right)$. These treatments are expensive, but stringent regulations are making them popular and their cost is also decreasing (22). Even though solar energy can be used to harness UV as a cost-effective method, photocatalysis by combining $\mathrm{TiO}_{2}$ and UV rays achieve high efficiency only under high UV irradiation. Adding the Fenton reagent to this improves the efficiencies of both the systems by increasing lifetime and generating more reactant radicals. Combination of biological treatments and AOPs have been suggested as pre-treatment or post-treatment for increasing the efficiency of the treatments as well as reducing the costs (28). Integration of membrane processes with photoelectrooxidation has been suggested to enhance the reduction of COD levels in tannery effluent (53).

The CETPs in Tamil Nadu, with their zero liquid discharge (ZLD) policies, have fared better as compared to CETPs in Uttar Pradesh and West Bengal not only for wastewater treatment but also in terms of waste management post-production (1).

The achievement of ZLD requires water recovery and thermal evaporation of saline reject from RO (61). The saline reject from RO may be disposed into the sea but under control, while recovered water will help to deal with its shortage (62). There are tanneries in Tamil Nadu, that employ the RO process for wastewater treatment and the performance of some of them have been studied. The permeate capacity of each of the plants are different, but all of their rejects are sent for solar evaporation first and some reuse the permeate in their tanning processes (60). An expensive alternative to solar evaporation is multiple effect evaporators (MEE) (61). The wastewater streams in these tanneries are separated into chrome containing wastewater, high BOD and COD wastewater and high inorganic salt encompassing wastewater. Conventional treatment after chromium recovery reduced BOD by $93-95 \%$, sulphide by $70-86.4 \%$ and complete removal of chromium. TDS removal was however negligible by conventional methods. TSS, BOD and COD from RO permeate has been reported to be below detection level (BDL) in some tanneries. MBRs combined with RO can reduce TDS by $91.1 \%$ $(60,62)$. To achieve TDS discharge norms of composite tannery effluent, tertiary treated effluent from tanneries is mixed with treated effluent from slaughterhouses and domestic wastewater from nearby areas (61). This mixture is also being used for green development in some landlocked areas (63). Tanneries in Vaniambadi, Tamil Nadu practice preliminary treatment before their wastewater is sent to the CETP for further treatment. This CETP treats effluents from 130 tanneries. Chrome and nonchrome water are treated separately in the individual tanneries for better treatment of water. Chrome water is treated in chrome recovery units at individual tanneries. The primary treatment includes mechanical screening and alum dosing with polyelectrolytes. Clarifier liquid from this is sent to a storage tank and conveyed to an anoxic tank after fine filtration. From there it is moved to an aeration tank and then to MBR. The effluent is then given RO treatment. As mentioned earlier in this review, RO does away with TDS which falls below $500 \mathrm{mg} / \mathrm{L}$. The permeate can be reused and the reject can be evaporated to recover salts. Implementation of MBR combined with RO in other CETPs or IETPs in India can result in 100\% elimination of suspended solids as compared to the global average of $96.5 \%$ and large mitigation of chlorides by $97.8 \%$ as compared to the global average of only $36.5 \%(2)$.

\section{Discussion}

This literature review provided a comprehensive understanding of major wastewater treatment methods used in Indian ETPs. The treatment processes include physico-chemical processes, biological processes and membrane processes that broadly come under primary, secondary and tertiary treatments. Combination of chemicals in coagulation provides best results in primary treatment but it may prove to be costly due to increased chemical use. The combination of aerobic and anaerobic treatments provided the best results in biological treatment. Preliminary separation of chrome and non-chrome water along with the combination of MBRs with RO techniques after primary chemical treatment has produced the best results in terms of pollutant reduction as acknowledged by some authors in reviewed literature as well as by CPCB. Membrane processes are expensive, but the quality of treated water obtained can be reused to reduce the freshwater footprint of a tannery and evidence has been given that the treated water imparts better physical characteristics to leather than freshwater. The adoption of this technique by more CETPs and IETPs will help the Indian leather industry to become eco-friendlier and more sustainable.

\section{Way Forward}

There are several technologies available in India to treat the 
wastewater generated from tannery industries. Screening and grit removal can be practised before primary chemical coagulation and flocculation. The combination of alum and ferric chloride has given the best results.

In secondary treatment, the selection of technology depends on basic criteria like the desired and initial effluent quality, the area available, and the budget and cost for construction and operation of the treatment plant. For anaerobic reactors, especially UASB, sulphur content may be reduced by oxidation through injection with manganese sulphate as a catalyst if deemed economically feasible.

Tertiary or advanced treatments can only be recommended for the reuse of treated water. The treated effluent can be reused after removal of ions by passing through the RO membrane. RO reject handling and its treatment, and proper disposal is very tedious and costly because of higher TDS content. The RO reject may be used for irrigation after it is blended with the treated sewage water. TDS discharge norms in Tamil Nadu are already met by mixing treated tannery wastewater with domestic wastewater as mentioned earlier in the review. The dilution or treatment of sewage and tannery effluent must not be done together in anaerobic conditions (64). Aerobic processes are recommended for this. This treated effluent can be reused very economically after the blending ratio is decided, based on the TDS of treated effluent and treated sewage.

\section{Conclusions} follows:

The main findings of this literature can be summarised as

- Tannery effluent may be treated physico-chemically, chemically or biologically.

- The results of chemical coagulation are better when alum and ferric chloride are mixed instead of being used individually.

- Combination of the aerobic and the anaerobic processes gives the best results in the biological treatment step.

- Wastewater treated with the help of RO can be reused in the tanning process to reduce the freshwater footprint.

- The TDS in the RO reject can be diluted by mixing with treated domestic wastewater and used in irrigation or discharged.

\section{Acknowledgement}

I would like to thank my mentor, Dr Ravi Sharma, for his constant guidance and unwavering support while authoring this paper.

\section{Ethical issue}

Authors are aware of, and comply with, best practice in publication ethics specifically with regard to authorship (avoidance of guest authorship), dual submission, manipulation of figures, competing interests and compliance with policies on research ethics. Authors adhere to publication requirements that submitted work is original and has not been published elsewhere in any language.

\section{Competing interests}

The author declares that there is no conflict of interest that would prejudice the impartiality of this scientific work.

\section{References}

1. Gupta S, Gupta S, Dhamija P, Bag S. Sustainability strategies in the Indian leather industry: an empirical analysis. Benchmarking. 2018;25(3):797-814.

2. Central Pollution Control Board. Global good practices in industrial wastewater treatment and disposal/reuse, with special reference to common effluent treatment plants Central Pollution Control Board [Internet]. Ministry of Environment and Forests, Govt. of India. 2015 Available from: http://www.indiaenvironmentportal.org.in/files/file/Report_CETP_ GGP.pdf

3. Meenachi S, Kandasamy S. Review on Waste Water Treatment Methods in Tannery Waste Water. Int J Adv Sci Eng Res [Internet]. 2017;2(1):512-21. Available from: http://ijaser.in/common_src/journal_file/1493449771_cf8d743102_ 2_ijaser.pdf

4. Ahamed MIN, Kashif PM. Safety Disposal of Tannery Effluent Sludge : Challenges To Researchers- a Review. Int J Pharma Sci Res [Internet]. 2014;5(10):733-6. Available from: https://www.researchgate.net/profile/Niyas_Ahamed/publication/30 3170418_Safety_disposal_of_tannery_effluent_sludge_challenges_t o_researchers-a_review/links/57f86ee108ae8da3ce5917be/Safetydisposal-of-tannery-effluent-sludge-challenges-to-researchers-a-rev

5. Singh SC, Gupta D. Sustainability: A Challenge for Indian Leather Industry. J Supply Chain Manag Syst [Internet]. 2013;2(4):37-43. Available from: http://www.influenceoutsourcing.com/wpcontent/uploads/2017/12/sustainability-.pdf

6. Bharose R, Parveen S, Singh D. Assessment of Physico-Chemical Properties of Tannery Waste Water and Its Impact on Fresh Water Quality. Int J Curr Microbiol Appl Sci. 2017;6(4):1879-87.

7. Sharma S, Malaviya P. Bioremediation of Tannery Wastewater by Aspergillus flavus SPFT2. Int J Curr Microbiol Appl Sci. 2016;5(3):137-43.

8. Sugasini A, Rajagopal K. Characterization of Physicochemical Parameters and heavy metal Analysis of Tannery Effluent. Int J Curr Microbiol Appl Sci [Internet]. 2015;4(9):349-59. Available from: https://www.researchgate.net/profile/Sugasini_Arasappan/publicatio n/282842698_Characterization_of_Physicochemical_parameters_an d_heavy_metal_analysis_of_tannery_effluent/links/561dec1808ae5 0795afd85eb/Characterization-of-Physicochemical-parameters-andhea

9. Mohanakavitha T, Shankar K, Divahar R, Meenambal T, Saravanan R. Impact of industrial wastewater disposal on surface water bodies in Kalingarayan canal, Erode district, Tamil Nadu, India. Arch Agric Environ Sci [Internet]. 2019 Dec 10;4(4):379-87. Available from: http://www.aesacademy.org/journal/volume4/issue4/AAES-04-0403.pdf

10. Ahamed MIN, Chandrasekaran N, Mukherjee A. Biochemical Analysis of Tannery Effluent. Int J Pharm Pharm Sci [Internet] 2014;6(7):644-5. Available from: https://www.researchgate.net/publication/266030847_Biochemical_ analysis_of_tannery_effluent

11. Prabhu M, Davamani V, Gopitha G, Sudhagar G, Jeevarekha P, Jeevitha $\mathrm{J}$, et al. Biosorption of Chromium from Tannery Effluent Using Bacterial and Fungal Species. Madras Agric J [Internet]. 2017;104(4-6):148-51. Available from: http://masujournal.org/104/104-4-6-148-151.pdf

12. Tripathi M, Upadhyay SK, Kaur M, Kaur K. Toxicity concerns of hexavalent chromium from tannery waste toxicity concerns of hexavalent chromium from tannery waste. J Biotechnol Bioeng [Internet]. 2018;2(2):40-4. Available from: https://www.researchgate.net/profile/Sudhir_Upadhyay/publication/ 328146268_Toxicity_Concerns_of_Hexavalent_Chromium_from_T annery_Waste/links/5e7077fb299bf14570f2902b/ToxicityConcerns-of-Hexavalent-Chromium-from-Tannery-Waste.pdf

13. Nagpure NS, Srivastava R, Kumar R, Dabas A, Kushwaha B, Kumar $\mathrm{P}$. Assessment of pollution of river ganges by tannery effluents using genotoxicity biomarkers in murrel fish, channa punctatus (Bloch). 
Indian J Exp Biol [Internet]. 2015;53(7):476-83. Available from: http://nopr.niscair.res.in/handle/123456789/31743

14. Bhavya KS, Raji P, A. JS, Samrot A V., Javad PTM, V. V. S. S. A. Leather processing, its effects on environment and alternatives of chrome tanning. Int $\mathrm{J}$ Adv Res Eng Technol [Internet]. 2019;10(6):69-79. Available from: http://www.iaeme.com/IJARET/issues.asp?JType=IJARET\&VType $=10 \&$ IType $=6$

15. Sreenivasan RS, Moorthy PK. Biochemical Stress of Chromium in Tannery Effluents on the Fresh Water Fish , Tilapia mossambica ( Pisces ). Int J Biol Med Res [Internet]. 2011;2(3):616-20. Available from:

http://citeseerx.ist.psu.edu/viewdoc/download?doi=10.1.1.302.1926 $\&$ rep=rep1\&type $=$ pdf

16. Kavitha PR, Ganapathy GP. Tannery process and its environmental impacts a case study: Vellore District, Tamil Nadu, India. J Chem Pharm Sci [Internet]. 2015;8(4):757-62. Available from: https://www.researchgate.net/profile/Ganapathy_Ganapathy/publica tion/297372024_Tannery_process_and_its_environmental_impacts_ a_case_study_Vellore_District_Tamil_Nadu_India/links/5da6df51a 6 fdccdad54648f8/Tannery-process-and-its-environmental-impactsa-case

17. Rangasamy S, Purushothaman G, Alagirisamy B. Chromium contamination in soil and groundwater due to tannery wastes disposals at Vellore district of Tamil Nadu. Chromium Contam soil Groundw due to Tann wastes disposals Vellore Dist Tamil Nadu. 2015;6(1):114-24.

18. Goswami S, Mazumder D. Scope of biological treatment for composite tannery wastewater. Int $\mathrm{J}$ Environ Sci [Internet]. 2014;5(3):607-22. Available from: https://www.indianjournals.com/ijor.aspx?target=ijor:ijes\&volume= $5 \&$ issue $=3 \&$ article $=013$

19. Roy C. A Study on Environmental Compliance of Indian Leather Industry \& its Far-reaching Impact on Leather Exports. Foreign Trade Rev. 2012;47(2):3-36.

20. PC S. Advances in Recycling and Waste Management. Adv Recycl Waste Manag. 2016;1(1):1-10.

21. Goswami S, Mazumder D. Treatment of Chrome Tannery Wastewater by Biological Process - A Mini Review. Int J Environ Ecol Eng [Internet]. 2013;7(11):798-804. Available from: https://pdfs.semanticscholar.org/eea7/99479933411e7bda2bebcf100 ec3b12b1d8a.pdf

22. Saxena G, Bharagava RN. Organic Pollutants in Tannery Wastewater and Bioremediation Approaches for Environmental Safety. In: Bioremediation for Industrial Pollutants [Internet]. 2016. p. 119-51. Available

from: https://www.researchgate.net/profile/Gaurav_Saxena2/publication/3 01680559_Organic_Pollutants_in_Tannery_Wastewater_and_Biore mediation_Approaches_for_Environmental_Safety/links/5bbc425f9 2851c7fde3703d7/Organic-Pollutants-in-Tannery-Wastewater-andBioremedi

23. Yadav A, Mishra S, Kaithwas G, Raj A, Bharagava RN. Organic pollutants and pathogenic bacteria in tannery wastewater and their removal strategies. Microbes and environmental management. In: Microbes and Environmental Management [Internet]. New Delhi: Studium Press (India) Pvt. Ltd.; 2016. p. 101-27. Available from: https://www.researchgate.net/profile/Ram_Bharagava/publication/2 90709995_Organic_Pollutants_and_Pathogenic_Bacteria_in_Tanne ry_Wastewater_and_their_Removal_Strategies/links/56ee8e1b08ae 4b8b5e74fbe9/Organic-Pollutants-and-Pathogenic-Bacteria-inTannery-Was

24. Durai G, Rajasimman M. Biological Treatment of Tannery Wastewater - A Review. J Environ Sci Technol. 2011;4(1):1-17.

25. Subramani T, Haribalaji D. Biodegradation of tannery effluent and designing the reactor for clarifier and activated sludge process. Int $\mathrm{J}$ Mod Eng Res [Internet]. 2012;2(3):774-81. Available from: http://citeseerx.ist.psu.edu/viewdoc/download?doi=10.1.1.416.1692 $\&$ rep=rep1\&type $=$ pdf
26. Saritha B, Ambica A, Sharmilaa G, Chmundeeswari J. Study Of Efficiency Of Ferric Chloride, Aluminium Sulphate And Their Combination For Treatment Of Tannery Effluent. Int J Eng Trends Technol [Internet]. 2011;1(3):7-14. Available from: https://www.researchgate.net/profile/Sharmilaa_Ganesan/publicatio n/283910651_Study_Of_Efficiency_Of_Ferric_Chloride_Aluminiu m_Sulphate_And_Their_Combination_For_Treatment_Of_Tannery _Effluent/links/564a0fff08ae295f644faf59/Study-Of-Efficiency-OfFerric-Chl

27. Borchate SS, Kulkarni GS, Kore S V, Kore VS. Application of Coagulation-Flocculation for Vegetable Tannery Wastewater. Int $\mathbf{J}$ Eng Sci Technol [Internet]. 2012;4(05):1944-8. Available from: https://www.academia.edu/download/47052060/IJEST12-04-05154.pdf

28. Selvabharathi G, Adishkumar S, Jenefa S, Ginni G, Rajesh Banu J, Yeom IT. Combined homogeneous and heterogeneous advanced oxidation process for the treatment of tannery wastewaters. J Water Reuse Desalin. 2016;6(1):59-71.

29. Naje AS, Abbas SA. Electrocoagulation Technology in Wastewater Treatment: A Review of Methods and Applications. Civ Environ Res [Internet]. 2013;3(11):29-42. Available from: http://sci.mu.edu.iq/wp-content/uploads/2017/04/paper-7-scopus1.pdf

30. Selvabharathi G, Adishkumar S, Banu JR. Removal of chromium(III) from tannery wastewater by electrochemical peroxidation process in a bench scale reactor. Desalin Water Treat. 2019;156(April 2018):340-8.

31. Sivakumar D. Biosorption of hexavalent chromium in a tannery industry wastewater using fungi species. Glob J Environ Sci Manag. 2016;2(2):105-24.

32. Sivakumar D, Murugan N, Rajeshwaran R, Shobana T, Soundarya C, Vanitha VS. Role of rice husk silica powder for removing $\mathrm{Cr}(\mathrm{VI})$ in a tannery industry wastewater. Int $\mathrm{J}$ ChemTech Res [Internet]. 2014;6(9):4373-8. Available from: https://www.researchgate.net/profile/Sivakumar_Durairaj2/publicati on/283365094_Role_of_rice_husk_silica_powder_for_removing_Cr _VI_in_a_tannery_industry_wastewater/links/56d282d408ae4d8d64 a5f6bf.pdf

33. Sivakumar D. Hexavalent chromium removal in a tannery industry wastewater using rice husk silica. Glob J Environ Sci Manag. 2015;1(1):27-40.

34. Abbas SH, Ismail IM, Mostafa TM, Sulaymon AH. Biosorption of heavy metals: A review. J Chem Sci Technol [Internet]. 2014;3(4):74-102. Available from: https://www.researchgate.net/profile/Ibrahim_Ismail6/publication/2 68022877_Bisorption_of_heavy_metals_A_review/links/545f4a660 cf295b56160e87b.pdf

35. Shamim S. Biosorption of Heavy Metals. In: Biosorption [Internet]. InTech; 2018. p. 21-49. Available from: http://dx.doi.org/10.1039/C7RA00172J\%0Ahttps://www.intechopen .com/books/advanced-biometric-technologies/liveness-detection-inbiometrics\%0Ahttp://dx.doi.org/10.1016/j.colsurfa.2011.12.014

36. Saranraj P, Sujitha D. Microbial Bioremediation of Chromium in Tannery Effluent: A Review. Int J Microbiol Res. 2013;4(3):305-20

37. Ayub S, Sharma PK, Tripathi CN. Removal of Hexavalent Chromium Using Agro and Horticultural Wastes as Low Cost Sorbents from Tannery Wastewater: A Review. Int J Res Civ Eng Archit Des [Internet]. 2014;2(3):21-35. Available from https://www.researchgate.net/profile/Sohail_Ayub2/publication/281 456982_Removal_of_Hexavalent_Chromium_Using_Agro_and_Ho rticultural_Wastes_as_Low_Cost_Sorbents_from_Tannery_Wastew ater_A_Review/links/55e92b4c08ae21d099c2e2f9.pdf

38. Sharma S, Malaviya P. Bioremediation of tannery wastewater by Aspergillus niger SPFSL2-a isolated from tannery sludge. Int J Basic Appl Sci [Internet]. 2013;2(3):88-93. Available from: http://www.crdeepjournal.org/wp-content/uploads/2013/07/Vol-2-33-IJBAS.pdf

39. Shankar D, Sivakumar D, Yuvashree R. Chromium (VI) removal 
from tannery industry wastewater using fungi species. Pollut Res [Internet]. 2014;33(3):505-10. Available from: https://www.researchgate.net/profile/Sivakumar_Durairaj2/publicati on/286304089_Chromium_VI_removal_from_tannery_industry_wa stewater_using_fungi_species/links/590debfe0f7e9b2863a4618c/Ch romium-VI-removal-from-tannery-industry-wastewater-using-fungispecies

40. Kurane AB, Attar YC. Biodegradation of tannery effluent by fungal species as a means of sustainable development. Stud Indian Place Names. 2020;40(42):258-66.

41. Sharma S, Malaviya P. Bioremediation of tannery wastewater by chromium resistant fungal isolate fusarium chlamydosporium SPFS2-g. Curr World Environ. 2014;9(3):721-7.

42. Jayanthi M, Kanchana D, Saranraj P, Sujitha D. Bioadsorption of Chromium by Penicillium chrysogenum and Aspergillus niger Isolated from Tannery Effluent. Int J Microbiol Res. 2014;5(1):40-7.

43. Sharma S, Adholeya A. Hexavalent Chromium Reduction in Tannery Effluent by Bacterial Species Isolated from Tannery Effluent Contaminated Soil. J Environ Sci Technol [Internet]. $2012 \mathrm{Mar}$ 1;5(3):142-54. Available from: http://www.scialert.net/abstract/?doi=jest.2012.142.154

44. Benazir JF, Suganthi R, Rajvel D, Pooja MP, Mathithumilan B. Bioremediation of chromium in tannery effluent by microbial consortia. African J Biotechnol. 2010;9(21):3140-3.

45. Mullick U. Simultaneous removal of Sulphate and Chromium from Tannery Waste using Microbes. National Institute of Technology; 2012.

46. Mythili K, Karthikeyan B. Bioremediation of Cr ( VI ) from Tannery effluent using Bacillus spp and Staphylococcus spp. Int Multidiscip Res J [Internet]. 2011;1(6):38-41. Available from: http://updatepublishing.com/journal/index.php/imrj/article/view/148 2

47. Bhattacharya A, Gupta A, Kaur A, Malik D. Simultaneous Bioremediation of Phenol and Cr (VI) from Tannery Wastewater Using Bacterial Consortium. Int J Appl Sci Biotechnol [Internet]. 2015;3(1):50-5 Available from: https://www.nepjol.info/index.php/IJASBT/article/view/11889

48. V K, M V, N R. Bioremediation of Tannery Effluents by Filamentous Cyanobacteria Anabaena Flos-Aquae West. Hydrol Curr Res [Internet]. 2011;2(5):1-4. Available from: https://www.omicsonline.org/bioremediation-of-tannery-effluentsby-filamentous-cyanobacteria-anabaena-flos-aquae-west-21577587.1000122.php?aid=2502

49. Sudarsan JS, Srihari V. Evaluation of adsorption capacity of biochar mixed substrate to treat tannery wastewater by constructed wetland. In: AIP Conference Proceedings [Internet]. AIP Publishing; 2019. p. 020176. Available from: http://aip.scitation.org/doi/abs/10.1063/1.5112361

50. Sasivarman B, Rajeshkannan M, Sowmiya V, Subashchandrabose E, Swetha R. Evaluation of Anaerobic Digester for Treating Tannery Effluent by Water Displacement Method. Int J Eng Technol [Internet]. 2018 Sep 22;7(4.2):40-2. Available from: https://www.sciencepubco.com/index.php/ijet/article/view/26328

51. Rajeswari A. Efficiency of effluent treatment plant and assessment of water quality parameters in tannery wastes. Eur J Exp Biol [Internet]. 2015;5(8):49-55. Available from: https://www.freeprojectsforall.com/wpcontent/uploads/2018/11/Sampling-Analysis-and-Design-ofEffluent-Treatment-Plant-for-Leather-Industry.pdf

52. Ramteke PW, Awasthi S, Srinath T, Joseph B. Efficiency assessment of Common Effluent Treatment Plant (CETP) treating tannery effluents. Environ Monit Assess. 2010;169(1-4):125-31.

53. Kothiyal M, Kaur M, Dhiman A. A comparative study on removal efficiency of sulphide and cod from the tannery effluent by using oxygen injection and aeration. Int J Environ Res. 2016;10(4):525-30.

54. Patil PG, Kulkarni GS, Kore S V., Kore VS. Aerobic Sequencing Batch Reactors for wastewater treatment - A review. Int J Eng Res Technol [Internet]. 2013;2(10):534-50. Available from:
https://www.academia.edu/download/36980137/V2I10-

IJERTV2IS100087.pdf

55. Suresh S, Tripathi RK, Rana MNG. Review on treatment of Industrial Wastewater using Sequential batch reactor. Int J Sci Technol Manag [Internet]. 2011;2(1):64-84. Available from: https://www.researchgate.net/profile/Dr_Suresh_Sundaramurthy/pu blication/265208578_2011_REVIEW_ON_TREATMENT_OF_IN DUSTRIAL_WASTEWATER_USING_SEQUENTIAL_BATCH_ REACTOR_IJSTM/links/540507db0cf23d9765a6cfe7/2011REVIEW-ON-TREATMENT-OF-INDUSTRIALWASTEWATER-USIN

56. Kaviyarasan K. Application of UASB Reactor in Industrial Wastewater Treatment-A Review. Int J Sci Eng Res [Internet]. 2014;5(1):584-9. Available from: http://www.ijser.org/researchpaper/Application-of-UASB-Reactorin-Industrial-Wastewater-Treatment.pdf

57. Tripathi M, Kumar S, Yadav SK, Pandey R, Tripathi P, Verma M. Modern Biological Methods for Treatment of Tannery Effluent. In: Tripathi M, editor. Microbial Treatment Strategies for Waste Management. Heathrow: OMICS International; 2019. p. 1-9.

58. Vinodhini PA, Sudha PN. Removal of heavy metal chromium from tannery effluent using ultrafiltration membrane. Text Cloth Sustain [Internet]. 2016;2(5):1-15. Available from: http://dx.doi.org/10.1186/s40689-016-0016-3

59. Bhattacharya P, Roy A, Sarkar S, Ghosh S, Majumdar S, Chakraborty $\mathrm{S}$, et al. Combination technology of ceramic microfiltration and reverse osmosis for tannery wastewater recovery. Water Resour Ind [Internet]. 2013;3:48-62. Available from: http://dx.doi.org/10.1016/j.wri.2013.09.002

60. Ranganathan K, Kabadgi SD. Studies on Feasibility of Reverse Osmosis (Membrane) Technology for Treatment of Tannery Wastewater. J Environ Prot (Irvine, Calif). 2011;02(01):37-46.

61. Rajamani S. Sustainable tannery effluent treatment system with TDS management. In: 35th IULTCS Congress 2019: "Benign by Design" Leather - The Future Through Science and Technology [Internet]. Oradea, Romania; 2019. p. 137-42. Available from: http://textile.webhost.uoradea.ro/Annals/Vol XX $\quad$ nr. 1 2019/Pielarie/Art. no. 365 pag. 137-142.pdf

62. Rajamani SG. Innovative environmental technologies including water recovery for reuse from tannery and industrial wastewater Indian and Asian scenario. ICAMS Proc Int Conf Adv Mater Syst. 2016;0.

63. Rajamani S. Sustainable environmental technologies including water recovery for reuse from tannery and industrial wastewater - indian and asian scenario [Internet]. Annals of the University of Oradea Fascicle of Textiles-Leatherwork. Oradea, Romania; 2017. p. 173-8. Available from: http://masujournal.org/104/104-4-6-148-151.pdf

64. Tare V, Nema A. UASB Technology - Expectations and Reality [Internet]. Kanpur and New Delhi; 2010. Available from: http://unapcaem.org/ActivitiesFiles/A01/UASBTechnologyExpectationsandReality.pdf 